\title{
Acquired ventricular septal defect following surgery for aortic valve endocarditis
}

\author{
Labib Syed (1) , ${ }^{1}$ Alex Shipolini, ${ }^{2}$ Habib Syed $(1),{ }^{3}$ Mohammed Y Khanji ${ }^{2}$
}

${ }^{1}$ Princess Alexandra Hospital NHS Trust, Harlow, UK ${ }^{2}$ Cardiology, Barts Health NHS Trust, London, UK

${ }^{3}$ Brighton and Sussex Medical School, Brighton, UK

\section{Correspondence to} Mr Labib Syed;

Labib.syed8@gmail.com

Accepted 12 May 2020
Check for updates

(C) BMJ Publishing Group Limited 2020. No commercial re-use. See rights and permissions. Published by BMJ.

To cite: Syed L, Shipolini A,
Syed H, et al. BMJ Case
Rep 2020;13:e234406.
doi:10.1136/bcr-2020-
234406

\section{DESCRIPTION}

A 52-year-old Caucasian man presented with a 3 -week history of productive cough, diaphoresis, fever, malaise and pleuritic chest pain. On examination he was tachycardic (heart rate 130 beats/ $\mathrm{min}$ ) and normotensive $(131 / 59 \mathrm{mmHg})$ with quiet heart sounds and no audible murmurs. Chest radiography showed bilateral pulmonary consolidation and arterial blood gas revealed type 1 respiratory failure requiring intubation and mechanical ventilation. Subsequently, the patient had two failed extubations and following this was transferred to a specialised cardiac centre. Initial transthoracic echocardiogram (TTE) revealed mild-to-moderate aortic regurgitation (AR) with no obvious vegetations. Blood cultures grew Streptococcus oralis

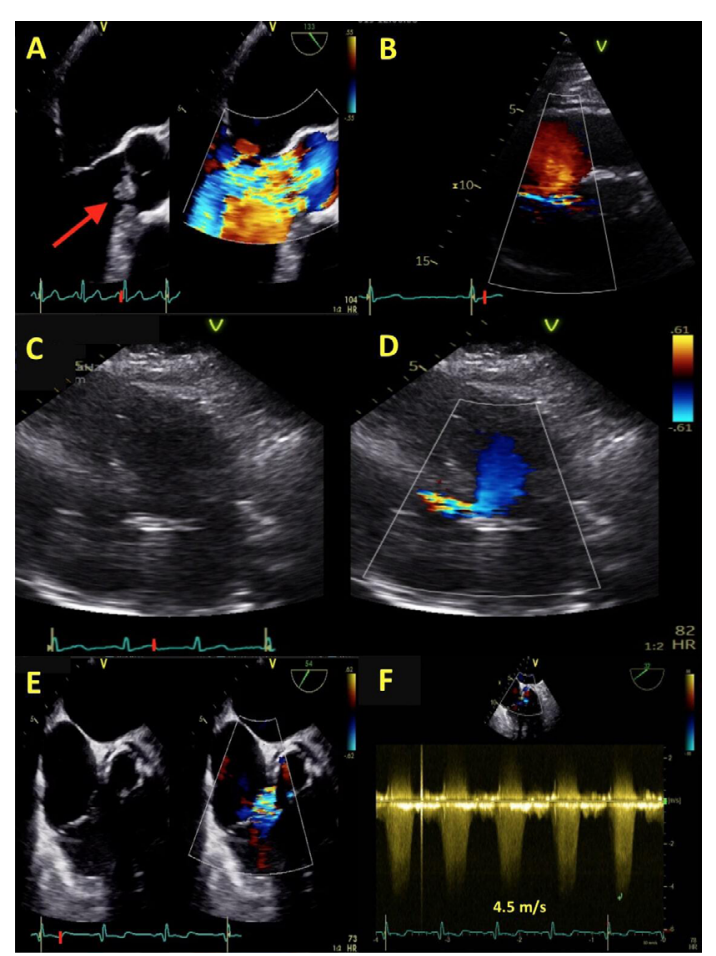

Figure 1 (A) Transoesophageal echocardiogram (TOE) indicating aortic valve vegetation (red arrow) causing severe anteriorly directed aortic regurgitation. (B) Postoperative transthoracic echocardiogram short axis view at the level of the aortic valve, showing a turbulent left-to-right systolic flow across the ventricular membranous septum. Also, seen in a modified fourchamber view (with and without colour flow (C) and (D), respectively) and in postoperative TOE (E) with a high velocity across the ventricular septal defect on continuous wave Doppler assessment (F) suggesting a small-sized shunt.

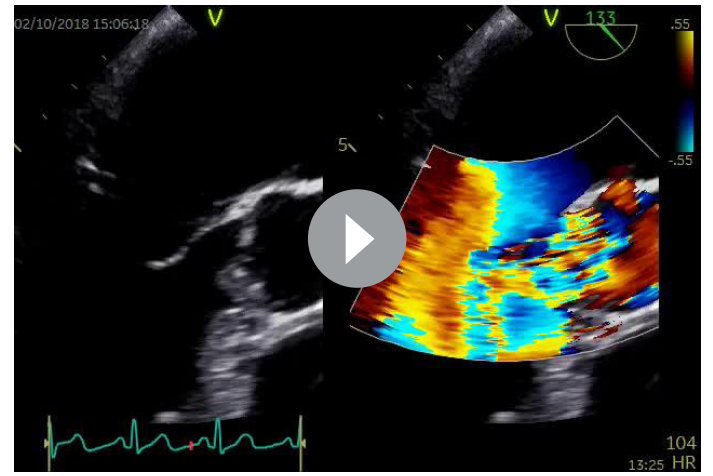

Video 1. Pre-op transoesophageal echocardiogram showing aortic valve vegetations causing severe aortic regurgitation.

sensitive to penicillin, despite not having any history of dental problems or interventions. Repeat TTE 8 days later demonstrated severe eccentric AR with a large $1.3 \mathrm{~cm}$ vegetation on the aortic valve, which is a $1 \mathrm{~A}$ indication for surgery. Subsequent transoesophageal echocardiogram (TOE) confirmed these findings as well as excluding an aortic root abscess (figure 1A, video 1). He was treated for infective endocarditis (IE) with intravenous benzylpenicillin and gentamycin.

He underwent emergency tissue aortic valve replacement (AVR) with a $23 \mathrm{~mm}$ Perimount Magna Ease with a successful outcome. However, 2 weeks postoperatively a loud pansystolic murmur was heard all over the precordium. Repeat TTE showed a turbulent systolic flow across the ventricular membranous septum with a left-to-right shunt, with Qp/Qs ratio of 1.2, consistent with a small restrictive membranous ventricular septal defect (VSD) (figure 1B-D and videos 2 and 3). Postoperative

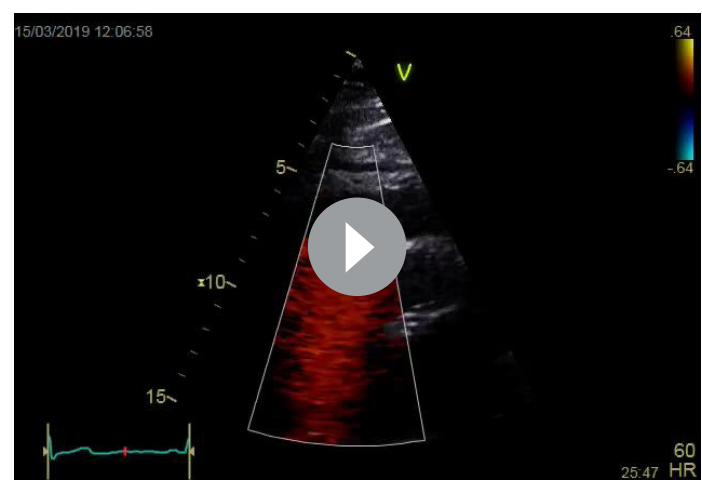

Video 2. Postoperative transthoracic echocardiogram short axis view just below the aortic valve level, showing a left-to-right systolic flow. 


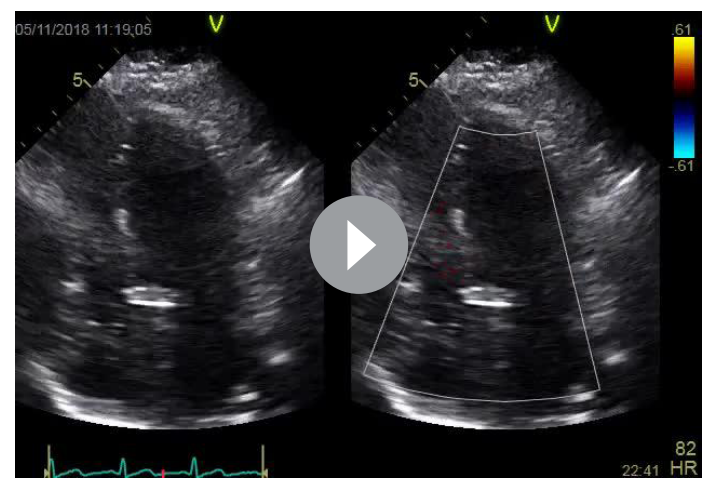

Video 3. Modified four-chamber transthoracic echocardiogram view with and without colour flow demonstrating left-to-right shunt across the interventricular septum.

TOE confirmed the VSD with a peak velocity of $4.54 \mathrm{~m} / \mathrm{s}$ and gradient of $83 \mathrm{mmHg}$ (figure $1 \mathrm{E}, \mathrm{F}$ and video 4 ). The endocarditis multidisciplinary team decision was to treat conservatively. He remained well at 10-month follow-up with no progression of the VSD on repeat echocardiography.

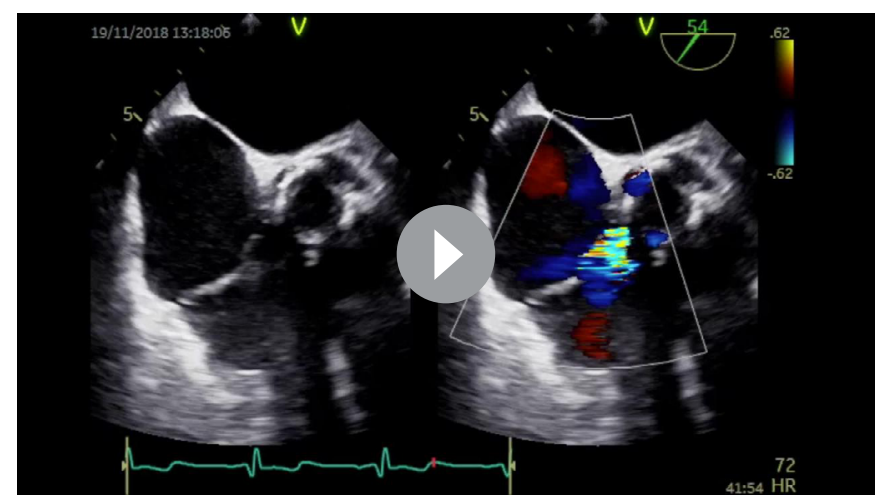

Video 4. Post-op transoesophageal echocardiogram confirming the turbulent systolic flow across the small ventricular septal defect.

\section{Learning points}

- The restrictive ventricular septal defect (VSD) was an incidental finding 2 weeks following aortic valve replacement (AVR). This highlights the importance of clinical examination and a postoperative echocardiogram roughly 6 weeks after AVR to exclude such complications.

- Management of a restrictive VSD post AVR should be determined on assessment of haemodynamic parameters and the presence of haemolysis or anaemia.

- Optimal suturing can be challenging in tissue areas of thin composition in association with left ventricular hypertrophy, particularly if surrounding tissue is friable.

Acquired restrictive VSDs following AVR is a rare but recognised complication. The pathophysiology is unknown but is most likely a consequence of a mechanical tear in an area where the tissues are thin, and combined with the presence of left ventricular hypertrophy, causing additional stress on the sutures used to attach the valve. The conventional treatment for this complication is the use of an Amplatzer device via a percutaneous route. However, the indication for treatment depends on haemodynamic parameters assessing right ventricular strain and dilation, with a rise in pulmonary arterial pressure or the presence of significant anaemia due to haemolysis from the high velocity jet. The patient did not exhibit these complications from the VSD therefore, it was agreed not to repair the defect presently following review by the structural interventional cardiology team.

Contributors LS, HS, MK and AS contributed in writing the manuscript. LS and MK obtained the images and videos. LS combined the images and videos into appropriate format.

Funding The authors have not declared a specific grant for this research from any funding agency in the public, commercial or not-for-profit sectors.

Competing interests None declared.

Patient consent for publication Obtained.

Provenance and peer review Not commissioned; externally peer reviewed.

\section{ORCID iDs}

Labib Syed http://orcid.org/0000-0002-6815-3340

Habib Syed http://orcid.org/0000-0003-0461-0861

Copyright 2020 BMJ Publishing Group. All rights reserved. For permission to reuse any of this content visit https://www.bmj.com/company/products-services/rights-and-licensing/permissions/

BMJ Case Report Fellows may re-use this article for personal use and teaching without any further permission.

Become a Fellow of BMJ Case Reports today and you can:

- Submit as many cases as you like

- Enjoy fast sympathetic peer review and rapid publication of accepted articles

- Access all the published articles

- Re-use any of the published material for personal use and teaching without further permission

Customer Service

If you have any further queries about your subscription, please contact our customer services team on +44 (0) 2071111105 or via email at support@bmj.com.

Visit casereports.bmj.com for more articles like this and to become a Fellow 